\title{
A comparison of native and non-native small mammals in adjacent karst and volcanic soil regions in NE Luzon, Philippines
}

\author{
Danilo S. Balete ${ }^{1 \dagger}$, Lawrence R. Heaney ${ }^{1 *}$, And Eric A. Rickart ${ }^{2}$
}

\begin{abstract}
Small mammal communities that occur in habitats on volcanic soil substrates have been extensively studied on Luzon Island, but those that occur in forest over limestone are poorly known and have not been directly compared to those over volcanic soils. We conducted field surveys of small mammals in forest over limestone from ca. $100 \mathrm{~m}$ to $590 \mathrm{~m}$ elevation in the vicinity of Callao Cave, and in adjacent lowland dipterocarp forest over volcanic soil from $490 \mathrm{~m}$ to $900 \mathrm{~m}$, near the location of prior surveys from $1300 \mathrm{~m}$ to $1550 \mathrm{~m}$ on Mt. Cetaceo, an extinct volcanic peak in the northern Sierra Madre range. Despite moderately heavy disturbance to the habitats over karst (limestone) and moderate disturbance to forest over volcanic soils, we found native small mammals overall at levels of species richness and abundance similar to what we have documented elsewhere on Luzon over the same elevational range. Non-native mammals were present at all localities in the karstic habitat but were absent in all types of forest over volcanic soils, even in areas recovering from prior disturbance. Although non-natives were moderately common in karstic areas, they rarely were more common than native species, and non-native species were no more successful at invading the disturbed karstic habitat than the native species were at persisting there. The most abundant small mammal in dipterocarp forest over volcanic soil (Apomys sierra) was absent in karstic localities, despite occurring in adjacent areas at overlapping elevation. Overall, the difference between small mammals in karst and lowland dipterocarp forest was mainly due to species composition rather than total abundance. Comparisons with data from a prior study on the upper slopes of Mt. Cetaceo showed that total native species abundance was highest in montane and mossy forest, typically about three times higher than in lowland dipterocarp forest. We confirmed the current presence of one species, Apomys microdon, reported as a fossil from Callao Cave, but the apparent absence of one other, Batomys sp.; both were from deposits dated as ca. 65,000 BP. We also summarize information about large mammals in the study areas. Further study of mammals in the distinctive forest over limestone is clearly needed.
\end{abstract}

Keywords: biodiversity, biogeography, Cagayan Valley, disturbed forest, elevation, fossils, Muridae, Sierra Madre, Soricidae

\section{Introduction}

The island of Luzon supports a remarkably diverse and highly endemic fauna of non-flying mammals, with about 56 native species documented. About $93 \%$ of these are endemic to

\footnotetext{
${ }^{1}$ Field Museum of Natural History, 1400 S Lake Shore Drive, Chicago, IL 60605 USA; ${ }^{2}$ Natural History Museum of Utah, University of Utah, Salt Lake City, UT 84108 USA

*Corresponding email: lheaney@fieldmuseum.org

${ }^{* \dagger}$ deceased 1 July 2017

Date Submitted: 12 Septermber 2019

Date Accepted: 16 January 2021
}

the island, and $86 \%$ are members of two highly diverse Philippine endemic radiations of murid rodents, the tribe Phloeomyini, known as cloud rats, with 12 species on Luzon, and the tribe Chrotomyini, known as earthworm mice, with ca. 36 species on Luzon (Heaney et al., 2016a, b; Rowsey et al., 2018; Rickart et al., 2019). Field- and collection-based studies conducted since 2000 have shown a consistent pattern of species richness increasing with elevation, typically increasing from about four species in lowland forest to 6-12 in montane and mossy forest above $1500 \mathrm{~m}$. Because the cool, wet habitats that mountains support at high elevation are isolated from one another as "sky islands," there is a strongly consistent pattern wherein many of the mammals that reside on each isolated massif are locally endemic species. Virtually the only species among this diverse group that are geographically widespread are 
those with broad elevational ranges that extend into lowland forest. Thus, the pattern of diversity of mammals on Luzon is largely the result of speciation among isolated montane areas within the island (Balete et al., 2012; Heaney et al., 2014, 2016a, b; Justiniano et al., 2015; Rickart et al., 2019).

Because most montane areas on Luzon are the products of volcanic activity, most studies of mammals along elevational gradients have necessarily been conducted on mountains with volcanic soil substrates, with their distinctive plant communities (Fernando et al., 2008). Although these studies have been broadly representative of Luzon mountains, they allow limited assessment in forest on other soil types, specifically including two that are moderately widespread in the Philippines. Ultrabasic soils produced by weathering of ophiolites (which are areas of uplifted oceanic seafloor), which typically produce distinctive plant communities adapted to the nutrient-poor soils, have patterns of mammalian richness and endemism like those in forest on volcanic soils (Balete et al., 2009, 2011; Heaney et al., 2016a, b). Soils over karst produce plant communities adapted to the rugged landscapes and dry conditions produced by erosion of the underlying limestone (Fernando et al., 2008). Only two published studies of Luzon mammals have included karstic habitat. The first took place on a mountain (Mt. Irid) with a complex intermixture of karstic, volcanic, and ophiolitic soils, and so is not representative of exclusively karstic habitat (Balete et al., 2013a). The second, in Caramoan National Park in southeastern Luzon, took place in an area of exclusively lowelevation karstic habitat (Balete et al. 2013b); it provides a valuable point of comparison, but no volcanic mountains are nearby, thus eliminating the potential for a comparative study. Thus, it remains to be determined if karstic soils are associated with distinctive mammal communities, and if the patterns of species composition and richness differ from those on volcanic mountainsides.

The primary purpose of this paper is to present new information from adjacent areas of forest over karstic limestone and lowland dipterocarp forest over weathered volcanic soil in NE Luzon, reaching from the Cagayan River to nearby Mt. Cetaceo (peak at $1730 \mathrm{~m}$ ), as a first effort to determine how communities of small mammals differ in these habitats. We also make comparison of data from those two habitats to the results of similar surveys in montane and mossy forest at higher elevations on Mt. Cetaceo, based on data from a similar study (Duya et al., 2011). This provides a broad view of small mammal communities on the west-facing slope of the northern Sierra Madre, a portion of Luzon where these species have not been thoroughly studied previously (Duya et al., 2007, 2011). We also present data on ecological aspects of the species we studied, including diel activity patterns, degree of arboreality, and preference for seed vs. animal baits. We briefly note information about larger mammals, since such information is sparse over most of the Philippines.

Finally, we note a unique aspect to this study. The description of a previously unknown species of human, Homo luzonensis, from Callao Cave at an age of ca. 65,000 BP (Detroit et al., 2019), has highlighted the importance of this area for understanding the environment in which this species lived; this cave lies within the study area reported here. Further, the report of two fossil small mammals from Callao Cave (Heaney et al., 2011), Apomys microdon and a potentially previously unknown species of Batomys, raises the question of whether either of these species is still present in the karstic habitat near Callao Cave, which we will address here. On-going studies of additional fossil small mammals from the same and adjacent caves (Ochoa, Mijares, and Heaney, unpubl. data) will make the data presented here invaluable in interpreting the fossil record in future studies.

\section{Materials and Methods}

\section{Description of the study area}

Our study sites were located within the Peñablanca karst landscape, of which Callao Cave is the most prominent and popular feature, and on the lower slopes of Mt. Cetaceo, an extinct volcanic peak that lies east of the karst (Fig. 1). Together, they form the core of the Peñablanca Protected Landscape and Seascape (PPLS), which is the fourth largest protected area in the Philippines (118,108 ha), and is contiguous with the Northern Sierra Madre Natural Park (359,486 ha), the single largest protected area in the archipelago (Mallari et al., 2001; Ong et al., 2002). Our study localities all lie within the municipality of Peñablanca, northeast of Tuguegarao City (Fig. 1).

Geologically, the PPLS forms part of the Northern Sierra Madre subprovince of the Eastern Physiographic Province. This geological subprovince is bounded by two prominent topographic features: Mt. Cagua, an inactive volcano near the northeastern tip of Luzon, is the northernmost peak (ca. 1158 $\mathrm{m}$ ), and Mt. Anacuao $(1850 \mathrm{~m})$, in the south, is the highest peak. The lithographic units of the eastern flank consist largely of undifferentiated Cretaceous to Paleocene strata overlain by Quaternary alluvium and volcanics, while its western section is of Late Oligocene to Middle Miocene volcanics and sediments including reefal limestone that give rise to the Peñablanca karstic landscape (Bureau of Mines and Geo-Sciences, 1982; Yumul et al, 2009; Wolfe, 1988). 


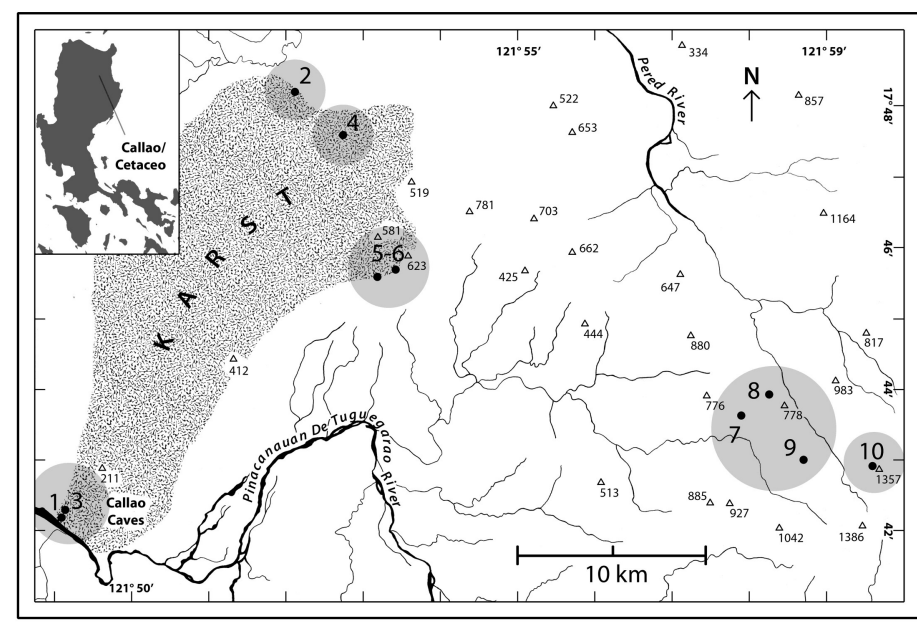

Figure 1. Map showing the study localities in the vicinity of the Callao Caves and adjacent portions of Mt. Cetaceo on Luzon, with inset showing the location on Luzon.

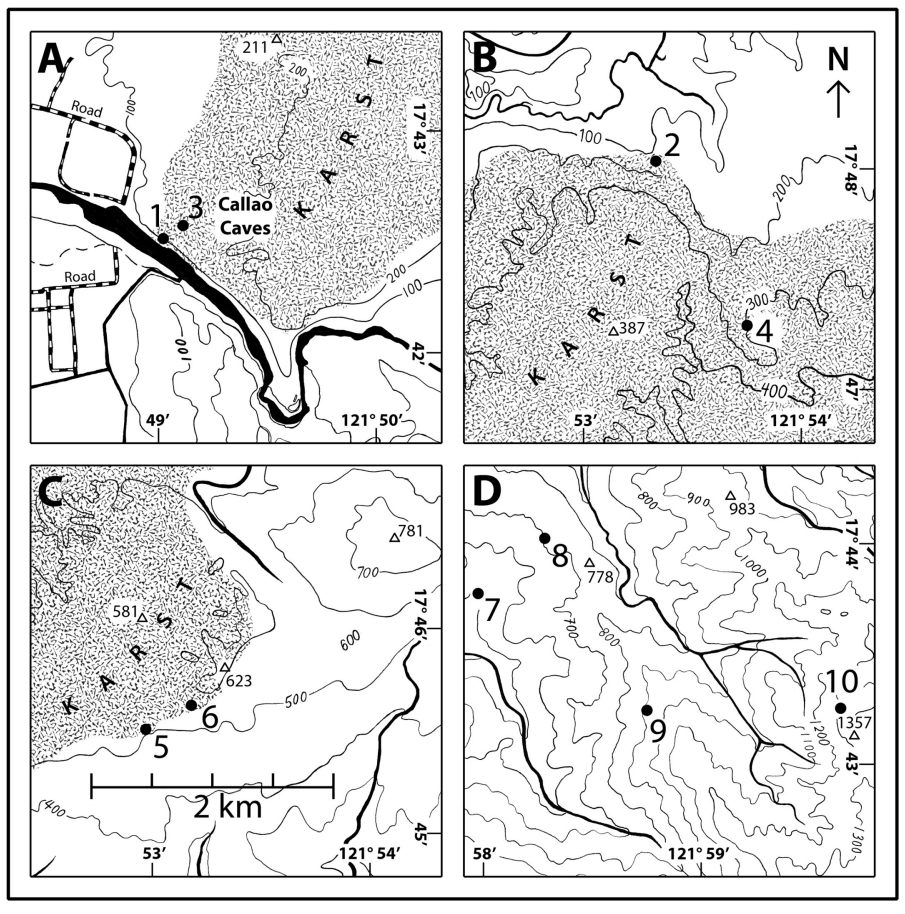

Figure 2. Maps showing detailed location of (A) Localities 1 and 3, closest to Callao Cave, (B) location of Localities 2 and 4, (C) location of Localities 5-6, and (D) location of Localities 7-10 on the lower slopes of Mt. Cetaceo. Sampling localities are indicated by solid circles, numbered as in the list of study areas (see Methods), with contour interval $=100 \mathrm{~m}$. Based on topographic maps from the National Mapping \& Resource Information Authority, Fort Bonifacio, Makati. The scale shown in $\mathrm{C}$ is the same in A, B, and D.

\section{Study localities}

Our field study was conducted in 2011 and 2012 on the western slope of the northern Sierra Madre, encompassed by the PPLS. In 2011 (30 May-1 July) we surveyed small mammals in regenerating forest over limestone of the Peñablanca karst at ca. $100-300 \mathrm{~m}$ elevation (Localities 1-4, Figs. 1 and 2A, B). The following year (25 January-19 February 2012) we covered two additional areas of the same karstic landscape at ca. 540-590 m elevation (Localities 5 and 6, Figs. 1 and 2C) and lowland dipterocarp forest at ca. 490-900 m elevation on Mt. Cetaceo (Localities 7-9, Figs. 1 and 2D). As noted below, the habitat at these nine localities was regenerating lowland forest in varying degrees of logging impact and in various stages of recovery. We know of no primary lowland forest that remains in the karstic areas or on the adjacent slopes of Mt. Cetaceo.

Locality 1. $9.1 \mathrm{~km} \mathrm{~N}, 3.5 \mathrm{~km}$ E Peñablanca town center, elevation $100 \mathrm{~m}\left(17.7070^{\circ} \mathrm{N}, 121.8173^{\circ} \mathrm{E}\right), 1-6$ June 2011 . We surveyed mammals in a narrow strip of forest along the bank of the Pinacanauan de Tuguegarao River, fronting the Callao Cave complex. The vegetation was regenerating forest over limestone but crowded with exotic reforestation species such as mahogany (Swietenia), Gmelina, and ipil-ipil (Leucaena), as well as narra (Pterocarpus), along with the remnant molave trees (Vitex), which likely formed much of the tree canopy prior to extensive anthropogenic disturbance. A few Cycas were observed at this site. The trees were mainly of low stature, ca. 7-10 m, with few reaching ca. $15 \mathrm{~m}$. Figs (Ficus) were abundant near the river banks. Extensive kaingin (slash and burn farms) surrounded this remnant patch.

Locality 2. $19.4 \mathrm{~km} \mathrm{~N}, 9 \mathrm{~km}$ E Peñablanca town center, elevation $100 \mathrm{~m}\left(17.8017^{\circ} \mathrm{N}, 121.8680^{\circ} \mathrm{E}\right), 21-26$ June 2011. We sampled mammals in regenerating forest over limestone adjacent to an expansive kaingin area, including a thin strip of riparian forest along a shallow stream bisecting the clearings. The forest was contiguous with Locality 4, with forest structure and composition like Localities 4 and 5. Along the shallow stream, the narrow strip of native trees, which was in the process of being completely cleared, included Artocarpus, Caryodaphnopsis, Celtis, Diospyros, Kleinhovia, Pterocarpus, and Terminalia, along with palms (Orania and Calamus). The clearings adjacent to the forest were planted mainly with corn and bananas but plots closer to the streams were planted with rice, vegetables, and root crops including sweet potato and taro. Coconut and large fruiting trees such as avocados, mangos, and guavas were common along the edges of clearings.

Locality 3. $9.5 \mathrm{~km} \mathrm{~N}, 3.7 \mathrm{~km}$ E Peñablanca town center, elevation $200 \mathrm{~m}\left(17.7121^{\circ} \mathrm{N}, 121.8187^{\circ} \mathrm{E}\right), 7-12$ June 2011. This locality was situated atop the Callao Cave complex on limestone hills immediately above Locality 1 . The vegetation at 
this site consisted of widely separated narrow strips of regenerating molave (Vitex) in which we conducted our sampling, surrounded by large expanses of grassland (Andropogon, Imperata, Saccharum, etc.) and kaingin. The cultivated areas were planted mainly with root crops (sweet potato and cassava), along with some coconuts and fruiting trees such as avocados and guavas. Trees scattered in the grassland consisted of molave, interspersed with Antidesma, Ficus, Tectona, and Trema. Climbing vines included Bauhinia, Derris, and Prainea. Trees were generally low, ca. 5-7 m, except on steep slopes where remnant trees up to ca. $15 \mathrm{~m}$ were found. Within remnant forest, understory trees were nearly absent; ground vegetation consisted mainly of grasses, along with few ferns, ground orchids, Lantana, and Zingiber. Grazing by cattle and water buffalo was widespread.

Locality 4. $18.9 \mathrm{~km} \mathrm{~N}, 9 \mathrm{~km}$ E Peñablanca town center, elevation $300 \mathrm{~m}\left(17.7977^{\circ} \mathrm{N}, 121.8683^{\circ} \mathrm{E}\right), 15-20$ June 2011. This area covered disturbed forest over limestone adjacent to Locality 2. The forest canopy height was ca. $15-20 \mathrm{~m}$, with emergent trees of up to $25 \mathrm{~m}$ high. Canopy and emergent trees included some dipterocarps (mostly Shorea), Celtis, Diospyros, Pterocarpus, and Syzygium; Vitex was rare. Saplings of canopy and emergent trees, Cycas, Calamus, Dracaena, and some Pandanus were the typical understory vegetation. Epiphytes, mainly orchids and ferns, were uncommon, but climbing bamboos (Dinochloa), lianas and other vines were common. Leaf litter was common on flatter ground, but the humus layer was thin, ca. $1 \mathrm{~cm}$.

Locality $5.14 .75 \mathrm{~km} \mathrm{~N}, 11 \mathrm{~km}$ E Peñablanca town center, elevation $540 \mathrm{~m}\left(17.7583^{\circ} \mathrm{N}, 121.8863^{\circ} \mathrm{E}\right), 25-30$ January 2012. We surveyed at this locality, northeast of the Callao Cave complex, in regenerating forest over limestone at the edge of expansive kaingin. As with Localities 2-4, the remaining forest was restricted to steep slopes that were entirely karstic and retained little topsoil; flatter ground with only intermittent limestone outcrops had been almost entirely cleared and planted with banana, cassava, corn, rice, sweet potato, taro, and fruit trees. Timber poaching in the remnant forest was rampant. Height of canopy and emergent trees was like Locality 4. Dipterocarps (Shorea) were present, along with narra, figs, Erythrina, Mangifera, and Syzygium; Vitex appeared to have been selectively cut and cleared long before and was rare at the site. Epiphytes were uncommon, consisting mainly of ferns and orchids. Canopy vines consisted mainly of climbing bamboos, rattans, and Tetrastigma. Saplings were common in the understory, along with Cinnamomun and other Lauraceae, Caryota, Dracaena, Garcinia, Leea, and a few Cycas. Ground cover plants included Alocasia, Amorphophallus, Begonia, Donnax, Pandanus, and Zingiber, as well as ground ferns and orchids. Leaf litter cover and a humus layer were present but thin, ca. $1-2 \mathrm{~cm}$.

Locality 6. $14.9 \mathrm{~km} \mathrm{~N}, 11.75 \mathrm{~km} \mathrm{E}$ Peñablanca town center, elevation $590 \mathrm{~m}\left(17.7607^{\circ} \mathrm{N}, 121.8904^{\circ} \mathrm{E}\right), 31$ January5 February 2012. This area was contiguous with Locality 5 and of similar forest formation; we surveyed remnant forest over limestone from ca. $560 \mathrm{~m}$ to $620 \mathrm{~m}$. The forest canopy was shorter than at Locality 5, ca. 10-12 m, with emergents of up to $15 \mathrm{~m}$. Figs and members of Lauraceae were present, along with Diospyros, oaks (Lithocarpus), Neonauclea, Syzygium, and Tristaniopsis. Signs of timber poaching were common; dipterocarps and Vitex were nearly absent. Composition of epiphytes, understory and ground cover vegetation was like Locality 5.

Locality 7. $2.65 \mathrm{~km} \mathrm{~N}, 9.15 \mathrm{~km} \mathrm{~W}$ Mt. Cetaceo peak, elevation $490 \mathrm{~m}\left(17.7309^{\circ} \mathrm{N}, 121.9672^{\circ} \mathrm{E}\right), 20-25$ February 2012. We surveyed at this locality in regenerating lowland dipterocarp forest on deeply weathered volcanic soils along an old logging road, on the northwest slope of Mt. Cetaceo. Logging at this site, which ended about 20 years ago, was selective, and there was a healthy recovery of forest vegetation. There were no signs of recent timber poaching. The canopy height was ca. 15-20 m, with emergent trees of up to ca. $25 \mathrm{~m}$. The dominant canopy and emergent trees included Shorea, Lithocarpus, Syzygium, Canarium, Diospyros, and Tristaniopsis. Ficus was abundant in the understory, especially near trails. Also common in the understory were palms (Calamus, Caryota, and Pinanga), pandans (Pandanus), and tree ferns (Cyathea). Ground cover vegetation was abundant, including ferns, orchids, Alocasia, Begonia, Donnax, and Zingiber. Ferns, mosses and orchids were the common epiphytes. Tetrastigma, jade vines (Strongylodon) and other lianas were the main canopy vines, along with climbing bamboos and rattans. Wild bananas (Musa) were present particularly near trails and streams, but generally uncommon in the forest interior. Leaf litter was abundant, and the humus layer was ca. $1-3 \mathrm{~cm}$.

Locality $8.3 \mathrm{~km} \mathrm{~N}, 8.75 \mathrm{~km} \mathrm{~W}$ Mt. Cetaceo peak, elevation $740 \mathrm{~m}\left(17.7343^{\circ} \mathrm{N}, 121.9714^{\circ} \mathrm{E}\right), 8-13$ February 2012. Forest at this locality was contiguous with Localities 7 and 9. It also shared with these two adjoining localities similar regenerating condition and vegetation composition, but the height of canopy and emergent trees was most similar to the formation of Locality 7.

Locality 9. $2.33 \mathrm{~km} \mathrm{~N}, 7.8 \mathrm{~km} \mathrm{~W}$ Mt. Cetaceo peak, elevation $900 \mathrm{~m}\left(17.7273^{\circ} \mathrm{N}, 121.9794^{\circ} \mathrm{E}\right), 14-19$ February 2012. Forest at this Locality was of similar formation, structure and species composition as at Localities 7 and 8, differing only in having relatively more intact forest cover than the former two localities. Moss cover appeared thicker on taller trees and the 
Table 1. Distribution of small mammals along an elevational gradient in forest over limestone in Peñablanca karst landscape. Values are captures at each locality, with captures/100 trap-nights indicated in parentheses. Values greater than expected from $X^{2}$ test, or from binomial test, based on number of trap-nights per locality are indicated in boldface.

\begin{tabular}{|c|c|c|c|c|c|c|c|c|c|}
\hline \multirow[b]{2}{*}{ Species } & \multicolumn{7}{|c|}{ Locality/Elevation (m) } & \multirow[b]{2}{*}{$X^{2}$} & \multirow[b]{2}{*}{$P$} \\
\hline & $\begin{array}{c}1 \\
100\end{array}$ & $\begin{array}{c}2 \\
100\end{array}$ & $\begin{array}{c}3 \\
200\end{array}$ & $\begin{array}{c}4 \\
300\end{array}$ & $\begin{array}{c}5 \\
540\end{array}$ & $\begin{array}{c}6 \\
590\end{array}$ & Total & & \\
\hline Suncus murinus & $2(0.34)$ & $3(0.31)$ & $1(0.11)$ & $0^{\mathrm{a}}$ & $0^{\mathrm{a}}$ & $2(0.20)$ & $8(0.16)$ & & \\
\hline Apomys microdon & $2(0.18)$ & $1(0.35)$ & $0^{\mathrm{a}}$ & $0^{\mathrm{a}}$ & $1(0.30)$ & $0^{\mathrm{a}}$ & $4(0.06)$ & & \\
\hline Apomys sp. & 0 & 0 & $1(0.11)$ & 0 & 0 & 0 & $1(0.02)$ & & \\
\hline Bullimus luzonicus & 0 & 0 & 0 & 0 & $2(0.33)$ & $3(0.30)$ & $5(0.10)$ & & \\
\hline Chrotomys mindorensis & 0 & $1(0.10)$ & 0 & 0 & 0 & 0 & $1(0.02)$ & & \\
\hline Rattus everetti & $2(0.34)$ & $\begin{array}{c}27 \\
(2.78)\end{array}$ & $\begin{array}{c}17 \\
(1.47)\end{array}$ & $9(0.92)$ & $7(1.16)$ & $\begin{array}{c}17 \\
(1.69)\end{array}$ & $\begin{array}{c}79 \\
(1.09)\end{array}$ & 16.47 & 0.002 \\
\hline Rattus exulans & 0 & $\begin{array}{c}4 \\
(0.41)\end{array}$ & $\begin{array}{c}\mathbf{1 3}^{\mathbf{c}} \\
(1.43)\end{array}$ & $0^{\mathrm{a}}$ & $1(0.16)$ & $1(0.10)$ & $\begin{array}{c}19 \\
(0.38)\end{array}$ & & \\
\hline Rattus tanezumi & $1(0.17)$ & $\begin{array}{c}2 \\
(0.20)\end{array}$ & $\begin{array}{c}14^{\mathrm{c}} \\
(1.54)\end{array}$ & $0^{\mathrm{a}}$ & $1(0.16)$ & $1(0.10)$ & $\begin{array}{c}19 \\
(0.38)\end{array}$ & & \\
\hline Total captures & $7(0.65)$ & $\begin{array}{c}\mathbf{3 8} \\
(3.02)\end{array}$ & $\begin{array}{c}46 \\
(3.98)\end{array}$ & $9(0.92)$ & $\begin{array}{c}12 \\
(1.28)\end{array}$ & $\begin{array}{c}24 \\
(2.38)\end{array}$ & $\begin{array}{c}136 \\
(1.88)\end{array}$ & 15.11 & 0.004 \\
\hline Total trap-nights (ground) & 579 & 972 & 909 & 980 & 603 & 1006 & 5049 & & \\
\hline Total trap-nights (arboreal) & 501 & 287 & 246 & 353 & 332 & 447 & 2166 & & \\
\hline $\begin{array}{l}\text { No.of native species } \\
+ \text { inferred }\end{array}$ & 2 & 3 & $\begin{array}{c}2 \\
+1\end{array}$ & $\begin{array}{c}1 \\
+1\end{array}$ & 3 & 2 & 5 & & \\
\hline $\begin{array}{l}\text { No. of non-native species } \\
+ \text { inferred }\end{array}$ & 2 & 3 & 3 & $\begin{array}{c}0 \\
+3\end{array}$ & $\begin{array}{c}2 \\
+1\end{array}$ & 3 & 3 & & \\
\hline
\end{tabular}

${ }^{\text {a }}$ presence inferred from occurrence at elevations above and below

${ }^{\mathrm{b}}$ only native species caught in ground traps included in $X^{2}$ tests

${ }^{\mathrm{c}}$ significantly more than expected based on binomial test, $\mathrm{P}<0.001$

presence of some podocarps was indicative of a transitional lowland-montane formation.

In addition to presenting the results of our new surveys, we also make use of previously published data on small mammals from four localities at high elevations on Mt. Cetaceo (Duya et al., 2011), included here as Localities 10-13. Sampling procedures from that study were the same as in the current study, and statistical tests used on data from the three habitats (karst, lowland dipterocarp, and montane forest) were the same as described below. Details regarding habitat at the four highelevation localities are provided in Duya et al. (2011). Locality 10 in Figure 1 is the geographically nearest of the Duya et al.
(2011) localities to those included in the current study.

\section{Field Methods and Data Analysis}

Our survey followed standard field techniques used during our past surveys of small mammals in the Philippines (e.g., Heaney et al., 1989, 1999, 2016a, 2016b; Rickart et al., 1991, 2011a, 2013; Balete et al., 2009, 2011, 2013a, 2013b; Alviola et al., 2011). Sampling was conducted along an elevational transect starting from the lowest available forest formation: regenerating forest over limestone starting at ca. $100 \mathrm{~m}$ (Locality 1) in the Peñablanca karst landscape and regenerating lowland dipterocarp forest over volcanic soil starting at ca. $490 \mathrm{~m}$ on Mt. 
Table 2. Summary of capture frequencies by bait type, diel period, and trap position of native small mammals along an elevational gradient in forest over limestone in Peñablanca karst landscape. Captures greater than expected from $X^{2}$ tests of ground traps with two bait types are shown in boldface. Correlation between elevation and trap success was tested with Spearman's correlations, $r_{s}$.

\begin{tabular}{|c|c|c|c|c|c|c|c|c|}
\hline & \multicolumn{6}{|c|}{ Locality/Elevation (m) } & \multirow[b]{2}{*}{ Totals } & \multirow[b]{2}{*}{$r_{\mathrm{s}}$} \\
\hline & $\begin{array}{c}1 \\
100 \\
\end{array}$ & $\begin{array}{c}2 \\
100 \\
\end{array}$ & $\begin{array}{c}3 \\
200 \\
\end{array}$ & $\begin{array}{c}4 \\
300 \\
\end{array}$ & $\begin{array}{c}5 \\
540 \\
\end{array}$ & $\begin{array}{c}6 \\
590 \\
\end{array}$ & & \\
\hline \multicolumn{9}{|l|}{ Coconut bait (ground) } \\
\hline Trap-nights & 407 & 758 & 809 & 850 & 519 & 753 & 4096 & \\
\hline Captures & 3 & 24 & 16 & 8 & 8 & 20 & 79 & \\
\hline Captures/100 trap-nights & 0.74 & 3.17 & 1.98 & 0.94 & 1.54 & 2.66 & 1.93 & 0.116 \\
\hline \multicolumn{9}{|l|}{ Earthworm bait (ground) } \\
\hline Trap-nights & 172 & 214 & 100 & 130 & 84 & 253 & 953 & \\
\hline Captures & 0 & 4 & 1 & 1 & 1 & 0 & 7 & \\
\hline Captures/100 trap-nights & 0 & 1.87 & 1.00 & 0.77 & 1.19 & 0 & 0.73 & -0.279 \\
\hline$X^{2}$ & & 0.97 & & & & 6.72 & 6.18 & \\
\hline$P$ & & 0.324 & & & & 0.010 & 0.013 & \\
\hline \multicolumn{9}{|l|}{ Overall trap success (\%) } \\
\hline Weighted & 0.52 & 2.88 & 1.87 & 0.92 & 1.49 & 1.98 & 1.70 & 0.116 \\
\hline Unweighted & 0.37 & 2.52 & 1.49 & 0.86 & 1.34 & 1.33 & 1.33 & -0.116 \\
\hline \multicolumn{9}{|l|}{ Coconut bait (arboreal) } \\
\hline Trap-nights & 501 & 287 & 246 & 353 & 332 & 447 & 2166 & \\
\hline Captures & 1 & 1 & 1 & 0 & 1 & 0 & 4 & \\
\hline Captures/100 trap-nights & 0.20 & 0.35 & 0.41 & 0 & 0.30 & 0 & 0.18 & 0.312 \\
\hline \multicolumn{9}{|l|}{ Diel period } \\
\hline Diurnal & 0 & 0 & 0 & 0 & 0 & 0 & 0 & \\
\hline Nocturnal/crepuscular & 7 & 38 & 46 & 9 & 12 & 24 & 132 & \\
\hline Percent diurnal & 0 & 0 & 0 & 0 & 0 & 0 & 0 & \\
\hline
\end{tabular}

Cetaceo (Locality 7). At each study locality, trapping was conducted continuously for six days; trap lines were maintained for three consecutive days before transferring to another site for three days. We used two types of snap traps, Museum Specials and Victor rat traps, for sampling small mammals. Traps were baited with either thinly sliced roasted coconut coated with peanut butter, or live earthworms. Traps were set either at ground level or up on tree branches and vines. Ground traps were set along runways beside rocks, tree trunks, and fallen logs, or under root tangles and leaning tree trunks. Arboreal traps were set on horizontal tree branches, overhanging lianas, and other vines, ca. $0.5-5 \mathrm{~m}$ above ground. Twice each day the traps were checked for captures and rebaiting: in the morning at ca. $700 \mathrm{H}$ and in the afternoon at ca. $1700 \mathrm{H}$. Captures were noted as either crepuscular/nocturnal when removed from traps during the morning check, or diurnal when caught between $700 \mathrm{H}$ and $1700 \mathrm{H}$. We measured our trapping effort by trapnights; a trap-night is equivalent to one trap set for $24 \mathrm{~h}$. During this study, we accumulated a total of 7,215 trap-nights in the
Peñablanca karst landscape, $70 \%$ of which was from ground trapping and 30\% from arboreal trapping (Table 1), and 3,470 trap-nights on Mt. Cetaceo, of which $86 \%$ was from ground trapping and $14 \%$ from arboreal trapping (Table 4). Coconut bait comprised from $81 \%$ to $87 \%$, and earthworm from $13 \%$ to $19 \%$, of the total ground trap-nights on the Peñablanca karst and on Mt. Cetaceo, respectively (Tables 1 and 4).

Captured animals were processed in the field as museum voucher specimens, either as fluid specimens or complete skeletons. Each specimen had a small tissue sample taken from the thigh and preserved in DMSO buffer solution before it was processed further, either by being injected with saturated formalin and soaked in $10 \%$ buffered formalin solution or skeletonized; fluid specimens were later transferred to $70 \%$ ethanol, and skeletons were cleaned with dermestid beetles before being soaked in a weak ammonia solution and then dried. All specimens were deposited at the Field Museum of Natural History, Chicago (FMNH) for verification of field identification and further taxonomic study, after which a portion of the 
Balete et al.: Mammals from karst and volcanic soils in NE Luzon

Table 3. Summary of captures of native small mammals by bait type, diel period and trap position along elevational gradient in forest over limestone in Peñablanca karst landscape. Captures greater than expected from $X^{2}$ test are shown in boldface.

\begin{tabular}{lccccccc}
\hline & \multirow{2}{*}{$\begin{array}{c}\text { Total } \\
\text { trapped }\end{array}$} & Coconut & Earthworm & $\begin{array}{c}\text { Nocturnal/ } \\
\text { Crepuscular }\end{array}$ & Diurnal & $\begin{array}{c}\text { Ground } \\
\text { surface }\end{array}$ & $\begin{array}{c}\text { Above } \\
\text { ground }\end{array}$ \\
\cline { 5 - 8 } & & & & & & & \\
Species & 4 & 4 & 0 & 4 & 0 & 1 & 3 \\
Apomys microdon & 1 & 1 & 0 & 1 & 0 & 1 & 0 \\
Apomys sp. & 5 & 4 & 1 & 5 & 0 & 5 & 0 \\
Bullimus luzonicus & 1 & 0 & 1 & 1 & 0 & 1 & 0 \\
Chrotomys mindorensis & 79 & $\boldsymbol{*}^{*} \mathbf{7 4}^{\mathrm{a}}$ & 5 & $* * * \mathbf{7 9}$ & 0 & $* * * \mathbf{7 8}$ & 1 \\
Rattus everetti & 90 & $\mathbf{8 3}^{\mathbf{a}}$ & 7 & $* * * \mathbf{9 0}$ & 0 & $* * * \mathbf{8 6}$ & 4 \\
TOTAL & & & & & & & \\
\hline
\end{tabular}

a only individuals caught in ground traps included in analysis

$* P<0.01$

$* * P<0.005$

$* * * P<0.001$

specimens will be returned to the Philippine National Museum of Natural History, Manila (PNM). The capture and handling of animals in the field was conducted in accordance with all relevant Philippine laws and regulations; nomenclature follows Heaney et al. (1998, 2010, 2016a).

Also following our previous studies, we assessed the adequacy of our sampling effort using species accumulation curves, by plotting the cumulative number of species captured against the number of trap-nights (all bait-types and trap positions) for each study locality, and cumulatively for all localities combined (lowest elevation to highest), for the Peñablanca karstic landscape (Localities 1-6) and lowland dipterocarp forest on Mt. Cetaceo (Localities 7-9). Trap success for each species at a given locality was measured in number of captures per 100 trap-nights. Bait preference was computed in the same manner, using the number of captures with each bait type and the relevant number of trap-nights. Weighted and unweighted (equalized) overall trap successes were also derived for each locality. The weighted trap success was determined by dividing the combined number of captures with both bait types by their combined trap-nights and multiplied by 100 ; unweighted trap success was calculated by averaging the trap success of the two bait types.

Significance of the differences in diel activity pattern as well as in the response to bait type and trap position was determined using chi-squared tests $\left(\chi^{2}\right)$. For bait type and trap position tests, the expected values were calculated on the basis of the number of relevant trap-nights; for diel activity, the expected frequency was computed from the proportion of diurnal $(10 \mathrm{~h})$ and nocturnal/crepuscular $(14 \mathrm{~h})$ activity time periods in a $24 \mathrm{~h}$ cycle. Only total samples of 20 or more individuals, with five or more individuals per "treatment" in at least $80 \%$ of the treatments (e.g., bait type) were subjected to $\chi^{2}$ tests. Spearman's coefficient of rank correlation $\left(r_{s}\right)$ was used to determine the relationship of elevation with species richness, relative abundance (number of individuals/trap-night), and diurnal activity (as percent of individuals).

\section{Results}

Forest over limestone. We accumulated a total of 7,215 trap-nights in forest over limestone, of which $70 \%$ was from ground trapping with coconut (4,096 trap-nights) and live earthworm (953 trap-nights) baits, and 30\% (2166 trap-nights) was from arboreal trapping with coconut bait only (Table 1). We captured 136 individuals representing eight species: five murid rodents are native to the Philippines (Apomys sp., A. microdon, Bullimus luzonicus, Chrotomys mindorensis, and Rattus everetti) and two are non-native pests ( $R$. exulans and $R$. tanezumi); the Asian house shrew, Suncus murinus, is also a non-native species. The single specimen that we refer to as Apomys sp. is currently unidentified but under study.

Species richness (presence and inferred presence) of native species in forest over limestone ranged from two to three (Table 1). Only A. microdon and $R$. everetti were present or inferred as present at all localities; $C$. mindorensis was present only at Locality $2(100 \mathrm{~m})$. Apomys sp. was captured only at Locality 3 $(200 \mathrm{~m})$, and B. luzonicus was recorded only at the two uppermost sites (540 and $590 \mathrm{~m}$ ). All three non-native species were present or inferred at all localities, except for $R$. exulans at Locality 1. At each locality we captured from four to 29 individuals of native small mammals, and from zero to nine individuals of non-native species, except at Locality 3 , where we captured 28 (Table 1). At each individual locality, the number of native species captured approached an asymptote by the second day of trapping, after an average of 400 trap-nights, except at 
A

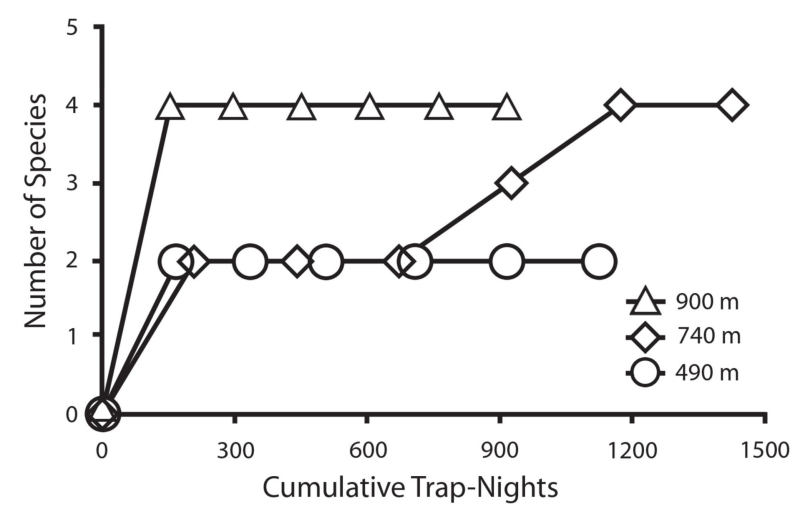

B

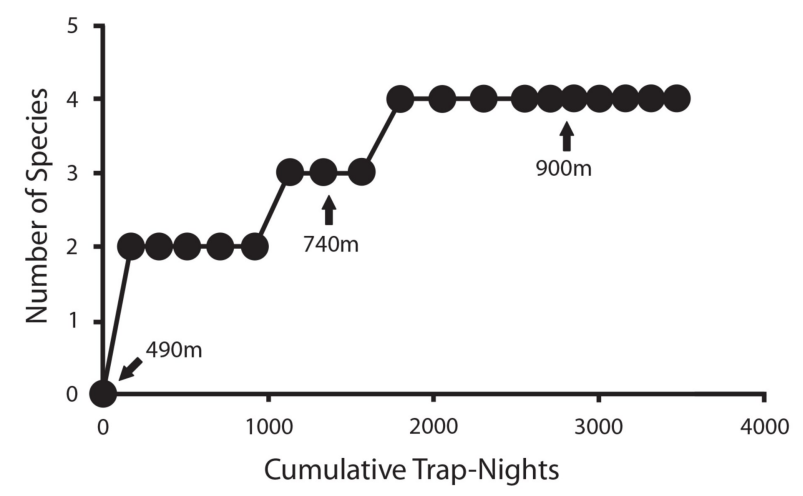

Figure 3. Species accumulation curves for native non-volant small mammals in forest over karstic limestone in individual study areas at Localities 1 through 6 (A) and for the entire karst transect (B), with the beginning of sampling at each location shown. Each symbol represents one day of sampling.

Localities 2 and 5 (Fig. 3A). The failure to reach a plateau at those two localities was due to our capture of an uncommon mouse, A. microdon, on the last day of trapping. However, since this species had been recorded previously at other localities along the transect, we feel confident that our trapping was successful in recording most of the species, without discounting the possibility that we missed some rare ones. Overall, our cumulative trapping effort reached an asymptote by 5,073 trapnights at Locality 5 ; we did not record any additional species throughout the rest of the survey (Fig. 3B).

Rattus everetti was the most abundant species, accounting for $87.8 \%$ of the total captures of native small mammals in forest over limestone, and was caught in significantly higher numbers, in ground traps at Localities 2, 3 and 6, than expected from $\chi^{2}$ tests. The remaining species were caught in numbers too small to allow a similar test (Table 1). Total captures of native species were significantly greater at Localities 2 and 3, where $R$. everetti predominated (Table 1). The number of individuals captured with coconut bait was significantly more than expected only at Locality 6 (Table 2), and overall captures were also significant for coconut bait (Table 3). No significant correlation of capture rates with elevation for either coconut bait or earthworms was evident along the karst transect (Table 2). Rattus everetti was caught in significantly higher numbers with coconut bait than expected from $\chi^{2}$ tests (Table 3). Captures during the nocturnal/crepuscular period, compared to daytime, was highly significant for $R$. everetti; we did not capture any native species during the day (Table 3). Similarly, captures of $R$. everetti on the ground surface significantly outnumbered arboreal captures $\left(\chi^{2}\right.$ test); only $A$. microdon was caught above ground, but sample size precludes a statistical test (Table 3 ). The dominance of $R$. everetti is reflected in total captures being also highly significant for coconut bait, during nocturnal/crepuscular period, and on the ground surface (Table 3). We were unable to conduct $\chi^{2}$ tests for non-native species because of low capture numbers.

We recorded the northern Luzon giant cloud rat or "buot," (Phloeomys pallidus), among climbing bamboos in the forest canopy at Locality 5 . We also obtained an individual at Locality 4 from local hunters who caught it from a hollow of a limestone boulder. This species was perceived by residents to be common in the remaining forest over limestone and was frequently hunted. The non-native palm civet, Paradoxurus philippinensis, was present at Localities 2-6; we observed their scats on rocks by riverbanks and on the ground, along trails in the forest. The Philippine warty pig, Sus philippensis, was also present in the remaining forest, and we observed signs of their presence at Localities 4-6. Local people reported to us that they often hunted palm civets and warty pigs. The Philippine brown deer (Rusa marianna) was not reported from the area. The longtailed macaque (Macaca fascicularis) was reported for this area by Duya et al. (2011) based on local hunters, but we saw none.

Lowland dipterocarp forest. Our trapping effort in lowland dipterocarp forests on Mt. Cetaceo consisted of 3,470 trapnights, of which 2,907 were on the ground (84\%) and $563(16 \%)$ were arboreal or above ground (Table 4). Coconut bait was used in 2,531 of ground trap-nights (87\%), and earthworm bait in the remaining $376(13 \%)$; only coconut bait was used in arboreal traps (Table 5). Our captures consisted of 95 individuals, representing four native species; we did not capture any nonnative pest rats (Tables $4 \& 6$ ). Native species consisted of three taxa that were also recorded in adjacent forests over limestone (A. microdon, B. luzonicus, and $R$. everetti), and one, the Sierra Madre forest mouse (A. sierrae), which we documented only in dipterocarp forests, where it was the most abundant species.

We recorded only two of the four species at $490 \mathrm{~m}$, and all four taxa at 740 and $900 \mathrm{~m}$, with captures ranging from two to 
Table 4. Distribution of native small mammals along an elevational gradient in lowland dipterocarp forest over volcanic soil on Mt. Cetaceo. Values are captures at each locality, with captures/100 trap-nights indicated in parentheses. In $X^{2}$ tests for values greater than expected based on number of trap-nights per locality, all were non-significant.

\begin{tabular}{|c|c|c|c|c|c|c|}
\hline \multirow[b]{2}{*}{ Species } & \multicolumn{3}{|c|}{ Locality/Elevation (m) } & \multirow[b]{2}{*}{ Total } & \multirow[b]{2}{*}{$X^{2}$} & \multirow[b]{2}{*}{$P$} \\
\hline & $\begin{array}{c}7 \\
490\end{array}$ & $\begin{array}{c}8 \\
740\end{array}$ & $\begin{array}{c}9 \\
900\end{array}$ & & & \\
\hline Apomys microdon & 0 & $1(0.24)$ & $1(0.11)$ & $2(0.06)$ & & \\
\hline Apomys sierrae & $23(2.35)$ & $17(1.68)$ & $19(2.07)$ & $59(2.03)$ & 1.14 & 0.566 \\
\hline Bullimus luzonicus & 0 & $2(0.20)$ & $5(0.54)$ & $7(0.24)$ & & \\
\hline Rattus everetti & $8(0.82)$ & $12(1.18)$ & $7(0.76)$ & $27(0.93)$ & 1.10 & 0.576 \\
\hline Total captures & $31(3.17)$ & $32(2.24)$ & $32(3.49)$ & $95(2.71)$ & 0.09 & 0.954 \\
\hline Total trap-nights (ground) & 977 & 1014 & 916 & 2907 & & \\
\hline Total trap-nights (arboreal) & 150 & 413 & 0 & 563 & & \\
\hline No. of native species & 2 & 4 & 4 & 4 & & \\
\hline No. of non-native species & 0 & 0 & 0 & 0 & & \\
\hline
\end{tabular}

59 individuals per species (Table 4). Species richness at each locality reached a plateau by 300 trap-nights at $490 \mathrm{~m}$ and 900 $\mathrm{m}$, but only toward the end of trapping at $740 \mathrm{~m}$ (Fig. 4A). Overall, our trapping effort reached an asymptote about halfway through the survey, by 1,798 trap-nights at $740 \mathrm{~m}$ (Fig. 4B); this indicated that our trapping effort successfully documented most species at each locality, although some rare species might have been missed.

There was no significant difference in overall trap success with elevation, whether weighted by number of traps baited with coconut and earthworms or unweighted ( $\chi^{2}$ test; Table 5). Coconut bait was more successful than live earthworms at our lowest site (Locality 7), but the reverse was evident at Locality 8 (Table 5); at our last site (Locality 9), the difference in trap success with either bait was slight and not significant. Apomys sierrae was the most common species (62\% of total captures), followed by $R$. everetti (28\%), but neither showed significant differences in capture rates with elevation or bait type; we caught too few individuals of $A$. microdon and B. luzonicus to allow statistical tests (Tables 5 and 6 ).

In total, we captured significantly more small mammals at night than during the day; this also was true individually for both $A$. sierrae and $R$. everetti (Table 6); only a single diurnal capture was recorded (A. sierrae). Overall, significantly more ground captures were recorded than arboreal captures. Three species, $A$. sierrae, B. luzonicus, and $R$. everetti, were caught only on the ground, and one $A$. microdon was caught in an arboreal trap (Table 6).
Local hunters told us that Phloeomys pallidus was present and hunted, but we did not observe any in the forest. During a previous study on Mt. Cetaceo, however, an individual of this species was observed at ca. $900 \mathrm{~m}$ (Duya et al., 2011). We observed few tracks of warty pigs, Sus philippensis, at our trapping localities, but we saw snares set for them in the forest below Locality 7 . We did not observe signs of the deer, Rusa marianna, but we met hunters who passed our camp at Locality 2, on their way to check snares for wild pigs and deer in montane and mossy forest (ca.1300-1700 m). We were told by hunters that both pigs and, especially, deer were becoming rare. Non-native palm civets, Paradoxurus philippinensis, were present at all localities, but based on their scats we observed along trails, they appeared uncommon in dipterocarp forest. Long-tailed macaques (Macaca fascicularis) were reported for this area by Duya et al. (2011; based on local hunters), but we saw none.

Comparison of small mammals in forest over limestone, lowland dipterocarp, and high-elevation forest. Data on the distribution and abundance of small mammals along the elevational gradient (100-1550 m), through forest over karstic limestone (six localities, 100-590 m), lowland dipterocarp forest over volcanic soil (three localities, 490-900 m), and four localities in montane and mossy forest over volcanic soil (1300$1550 \mathrm{~m}$; sometimes referred to as lower and upper montane forest; Fernando et. al, 2008) from our prior studies on Mt. Cetaceo (Duya et al., 2011) are summarized in Fig. 5.

Along this elevational and habitat transect, the non-native 
A

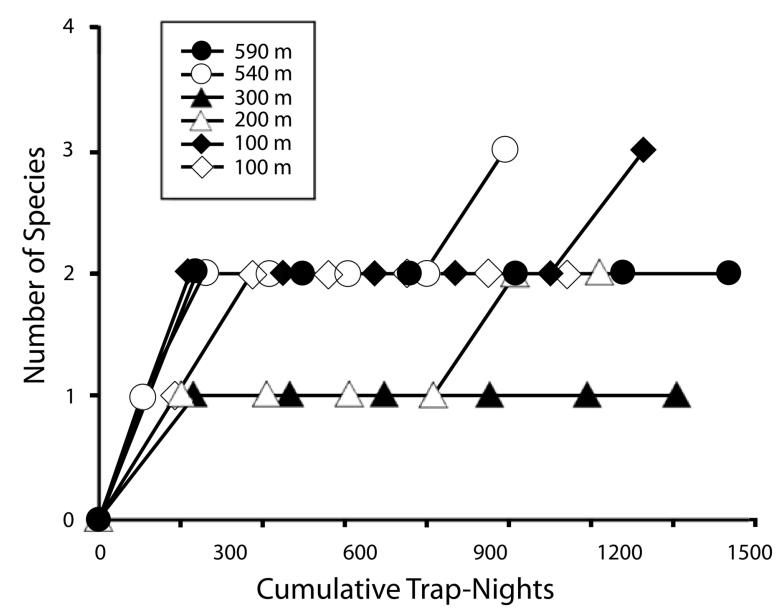

B

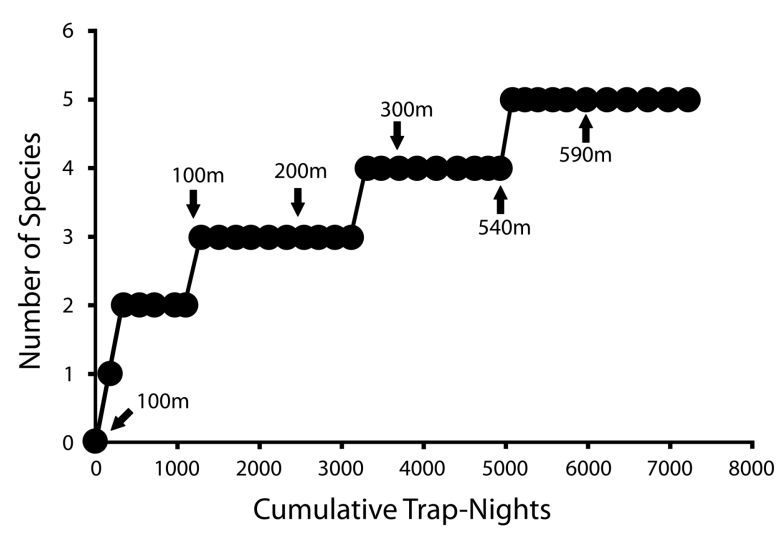

Figure 4. Species accumulation curves for native non-volant small mammals in lowland dipterocarp forest over volcanic soil at Localities 7 through 9 (A) and for the entire transect (B), with the beginning of sampling at each location shown. Each symbol represents one day of sampling.

shrew (S. murinus) and two non-native pest rats (R. exulans and $R$. tanezumi) were present only in karstic forest areas, all of which had been extensively disturbed (see description of study areas, above). These species were not captured in forest over volcanic soils (i.e., lowland dipterocarp, montane, and mossy forest), even at the lowest dipterocarp forest locality (490 m) that was near to, and lower in elevation, than upper karst localities (Figs. 1 and 5), where prior disturbance was evident. One native small mammal, Apomys sp., a member of the $A$. musculus group (Heaney et al., 2016a), was found only at Locality $3(200 \mathrm{~m})$, and the sole specimen captured of Chrotomys mindorensis was taken at Locality $2(100 \mathrm{~m})$, both in karstic habitat.

In contrast, three native species (A. microdon, $B$. luzonicus, and $R$. everetti) were present in all four habitat types, including most individual localities (Fig. 5). Apomys sierrae was the most abundant species at all localities over volcanic soils, but was absent from all karstic localities, even those that were higher in elevation than the lowest dipterocarp forest where $A$. sierrae was abundant. Additionally, several native species were present only at high elevation: Crocidura grayi, a native shrew, was present (or inferred) from $1400 \mathrm{~m}$ to $1550 \mathrm{~m}$; Apomys musculus was recorded at $1500 \mathrm{~m}$; and Soricomys musseri, a shrew-mouse endemic to high elevations in the northern Sierra Madre, was present only at $1500 \mathrm{~m}$ and $1550 \mathrm{~m}$ (Fig. 5).

Species richness of non-native mammals varied from one to three in karstic areas and was absent on volcanic soils. Native species ranged from two or three in karstic areas, to four in lowland dipterocarp forest, and four to six in montane and mossy forest. Total non-native species abundance (non-weighted captures per 100 trap-nights; see Methods) in karstic localities varied from zero at $300 \mathrm{~m}$ (with one species inferred but not captured) to 3.08 per 100 trap-nights at $200 \mathrm{~m}$. Total native species abundance was higher than non-natives at all but one of the karstic localities; in other words, although non-natives were

Table 5. Summary of capture frequencies by bait type, diel period, and trap position of native small mammals in lowland dipterocarp forest over volcanic soil on Mt. Cetaceo.

\begin{tabular}{|c|c|c|c|c|}
\hline & \multicolumn{3}{|c|}{ Locality/Elevation (m) } & \multirow[b]{3}{*}{ Totals } \\
\hline & 5 & 8 & 9 & \\
\hline & 490 & 740 & 900 & \\
\hline \multicolumn{5}{|l|}{ Coconut bait (ground) } \\
\hline Trap-nights & 870 & 865 & 796 & 2531 \\
\hline Captures & 30 & 24 & 28 & 82 \\
\hline Captures/100 trap-nights & 3.45 & 2.77 & 3.52 & 3.24 \\
\hline \multicolumn{5}{|l|}{ Earthworm bait (ground) } \\
\hline Trap-nights & 107 & 149 & 120 & 376 \\
\hline Captures & 1 & 7 & 4 & 12 \\
\hline Captures/100 trap-nights & 0.93 & 4.70 & 3.33 & 3.19 \\
\hline$X^{2}$ & 1.90 & 1.54 & 0.01 & 0.002 \\
\hline$P$ & 0.168 & 0.215 & 0.920 & 0.961 \\
\hline \multicolumn{5}{|l|}{ Overall trap success $(\%)$} \\
\hline Weighted & 3.17 & 3.06 & 3.49 & 3.23 \\
\hline Unweighted & 2.19 & 3.74-- & 3.42 & 3.22 \\
\hline \multicolumn{5}{|l|}{ Coconut bait (arboreal) } \\
\hline Trap-nights & 150 & 413 & 0 & 563 \\
\hline Captures & 0 & 1 & 0 & 1 \\
\hline Captures/100 trap-nights & 0 & 0.24 & 0 & 0.18 \\
\hline \multicolumn{5}{|l|}{ Diel period } \\
\hline Diurnal & 0 & 0 & 1 & 1 \\
\hline Nocturnal/crepuscular & 31 & 32 & 31 & 94 \\
\hline Percent diurnal & 0 & 0 & 3.12 & 1.05 \\
\hline
\end{tabular}


moderately common in karstic areas, they rarely were more common than native species. Total native species abundance was about equal in the three lowland dipterocarp localities (3.17 -3.49 per 100 trap-nights), and similar to their highest abundance in one karstic area (100 m, 3.19 per 100 trap-nights). Total native species abundance was highest in montane and mossy forest, typically about three times higher than in lowland dipterocarp forest (Fig. 5).

Duya et al. (2011) presented anecdotal evidence that deer (Rusa marianna) were uncommon and declining in abundance at high elevation on Mt. Cetaceo, and the native warty pigs (Sus philippensis) were moderately common, with both reaching their greatest abundance at high elevations. They described nonnative Macaca fascicularis and Paradoxurus philippinensis and native cloud rats (Phloeomys pallidus) as present, and implied that all three were more common at lower elevations than high on the mountain.

Finally, we note that Apomys microdon, which was reported as a fossil from Callao Cave dated ca. 65,000 BP (Heaney et al., 2011), was present during our survey of karstic habitats, and nearby lowland dipterocarp and montane forests (Fig. 4). In contrast, we found no evidence that Batomys sp., present as a fossil of the same age, occurs in the area today; its geographically nearest relative (B. granti) occurs only in montane forest in the Central Cordillera, across the broad Cagayan River valley, and not in the Sierra Madre.

\section{Discussion}

The data presented here represent the first direct comparison of native small mammal faunas from adjacent areas of lowland forest over karstic limestone with forest over volcanic soils, the latter supporting lowland dipterocarp forest, montane forest, and mossy forest with both habitats occurring along elevational gradients. These two soil types are the most common and widespread in the Philippines, but only two previous studies of mammals have been conducted in forest over limestone, and neither was done in comparison with forest over volcanic soils (Balete 2013a, 2013b). Thus, this study provides new insights into previously little-studied aspects of Philippine mammal biodiversity.

However, before interpreting our results, we note that all our sampling areas in forest over limestone had undergone substantial degradation by logging, burning, and clearing for agriculture, as described in "Study Localities," above. The same was true for our sampling areas in lowland dipterocarp forest, but disturbance was less extensive, and it appeared that the ability of vegetation on this nutrient-rich volcanic soil to regenerate after disturbance was greater. Thus, the disturbance history of these two types of forest (Localities 1-6 and 7-9, respectively) differed; given that extent and history of disturbance has been shown in prior studies to have a significant impact on small mammals (e.g., Rickart, 1993; Rickart et al., 2007, 2011b; Reginaldo and de Guia, 2014; Stuart et al., 2008), care must be taken to not over-interpret our results.

Small mammals in karstic habitat. We found quite different communities of small mammals in forest over limestone compared to lowland dipterocarp forest (Fig. 5). Perhaps most dramatically, we found non-native species to be present or inferred at all forest over limestone localities, but apparently absent in forest over volcanic soils, even at localities in substantially disturbed lowland dipterocarp forest near forest over limestone. Clearly, non-native species were much more successful in invading these karstic areas than nearby forest habitats over volcanic soil.

In these karstic areas, native small mammals were as

Table 6. Summary of captures of native small mammals by bait type, diel period and trap position in lowland dipterocarp forest over volcanic soil on Mt. Cetaceo. Captures greater than expected from X2 test are shown in boldface.

\begin{tabular}{|c|c|c|c|c|c|c|c|}
\hline & \multirow[b]{2}{*}{$\begin{array}{c}\text { Total } \\
\text { trapped }\end{array}$} & \multicolumn{2}{|c|}{ Bait type } & \multicolumn{2}{|c|}{ Diel period } & \multicolumn{2}{|c|}{ Trap position } \\
\hline & & Coconut & Earthworm & $\begin{array}{c}\text { Nocturnal/ } \\
\text { Crepuscular }\end{array}$ & Diurnal & $\begin{array}{l}\text { Ground } \\
\text { surface }\end{array}$ & $\begin{array}{l}\text { Above } \\
\text { ground }\end{array}$ \\
\hline \multicolumn{8}{|l|}{ Species } \\
\hline Apomys microdon & 2 & 2 & 0 & 2 & 0 & 1 & 1 \\
\hline Apomys sierrae & 59 & 48 & 11 & $* * * 58$ & 1 & $* * 59$ & 0 \\
\hline Bullimus luzonicus & 7 & 7 & 0 & 7 & 0 & 7 & 0 \\
\hline Rattus everetti & 27 & 26 & 1 & $* * * 27$ & 0 & $* 27$ & 0 \\
\hline TOTAL & 95 & 83 & 12 & $* * * 94$ & 1 & $* * * 94$ & 1 \\
\hline
\end{tabular}

$* P<0.02$

$* * P<0.0007$

$* * * P<0.00001$ 
diverse and roughly as abundant as non-native species; indeed, at three of our six localities, total abundance of native species exceeded that of non-native species, and at another they were virtually equal (Fig. 5). In other words, non-native species were no more successful at invading disturbed karstic habitat than native species were at persisting there. This compares closely with results from other studies: native small mammals on Luzon are resistant to extinction from forest degradation as long as some native vegetation remains, and non-native species are successful at persisting only in places where forest degradation is great (e.g., Balete et al., 2013b; Rickart, 1993; Rickart et al., 2007, 2011b; Reginaldo and de Guia, 2014; Stuart et al., 2008).

With one exception (see below), native species that we found in the karstic habitat (Apomys microdon, Bullimus luzonicus, Chrotomys mindorensis, and Rattus everetti) are the same species that have been documented in many other areas of disturbed lowland forest on Luzon (e.g., Heaney et al., 2016a; Rickart et al., 2011b; Stuart et al., 2008), and, except for $C$. mindorensis, in the one area of extensive but disturbed karstic habitat previously studied (Balete et al., 2013b). The consistent tolerance of disturbance by these species is clearly at least partly responsible for their current widespread distribution; their presence at any given locality should not be interpreted as evidence of "good forest," but rather for forest vegetation at any level of disturbance. In that sense, they are "disturbance generalists," able to persist under many degrees of anthropogenic and natural disturbance. The fact that Rattus everetti was most abundant among these four is also the common pattern, as was our finding that this species strongly preferred coconut bait rather than earthworms, was active exclusively at night, and did so on the ground surface rather than in trees (Table 3); the same results were also found in disturbed karstic habitat in Caramoan National Park (Balete et al., 2013b). The one exception noted above is an unidentified species (Apomys sp.) we captured at Locality 3, represented by a single individual currently under study.

Small mammals in lowland dipterocarp forest. Beginning at $490 \mathrm{~m}$ in disturbed dipterocarp forest over volcanic soil (an elevation below our two highest karstic localities), we found a rather different community (Fig. 5). Apomys microdon, Bullimus luzonicus, and Rattus everetti remained at abundances like those in the karst, but Chrotomys mindorensis was absent. In a dramatic difference, Apomys sierrae was by far the most abundant species at every locality; as found in previous studies (Duya et al., 2011; Heaney et al., 2013), we found A. sierrae to be omnivorous (responding to both coconut and earthworm bait), active at night, and living exclusively on the ground (Table 6). The abundance of this large, widespread, groundliving, omnivorous forest mouse at $490 \mathrm{~m}$, and its apparent absence in karstic localities at $540 \mathrm{~m}$ and $590 \mathrm{~m}$, seems a clear indication, not of their inability to reach the karstic areas, but rather their inability to survive in karstic habitat. Further research should test this hypothesis, preferably in undisturbed forest over limestone, but given the dramatic differences, we predict that this pattern will remain. We note that species richness of native species in lowland dipterocarp forest was slightly greater (four species) than in karst localities (two to three), and their total abundance averaged higher than in karst, but their greatest abundance in karst (3.19 per 100 trap-nights) was near to the average (ca. 3.30) in lowland dipterocarp forest. Thus, the difference between small mammals in karst and lowland dipterocarp forest was mainly due to species composition rather than total abundance (Fig. 5).

Small mammals in highland forest. Our earlier studies at high elevation on Mt. Cetaceo (1300-1550 m; Duya et al., 2011), summarized in Figure 5, show an increase in species richness from four in lowland localities (490-900 m) to six in mossy forest at $1500 \mathrm{~m}$, along with a roughly five-fold increase in total abundance (from ca. 3.30 to 16.27 per 100 trap-nights). Along this transect, we captured Crocidura grayi (a small native shrew) only at $1400 \mathrm{~m}$ and $1550 \mathrm{~m}$, and Soricomys musseri (a small insectivorous mouse) only at $1500 \mathrm{~m}$ and $1550 \mathrm{~m}$. C. grayi is sometimes captured as low as sea level, and is often common above $800 \mathrm{~m}$, but $S$. musseri only occurs above about $1450 \mathrm{~m}$, as do its three congeners (Balete et al., 2012; Heaney et al., 2016a). This increase in species richness and abundance along elevational gradients on volcanic mountainsides is typical on Luzon; indeed, we see nothing unusual about the pattern of small mammal abundance in habitats on volcanic soils on Mt. Cetaceo.

Finally, we note that five large mammals (natives Phloeomys pallidus, Sus philippinensis, and Rusa marianna, and non-natives Macaca fascicularis and Paradoxurus philippensis) were present in the Callao-Cetaceo vicinity, with all probably occurring along the entire elevational gradient (except deer which was absent from karst); but local people reported that all were heavily hunted during our surveys, with deer populations disproportionately impacted.

In conclusion, we can summarize our findings rather simply: on volcanic soils that give rise to lowland dipterocarp forest, montane forest, and mossy forest on Mt. Cetaceo, species composition, richness, and abundance follow patterns we have seen repeated elsewhere on Luzon, including presence of some high-elevation endemics, but also an absence of non-native species (Heaney et al., 2016a). In contrast, in disturbed forest over karstic limestone, three non-native species were moderately abundant, even though native species richness and abundance are about what we would expect at this elevation (Balete et al., 


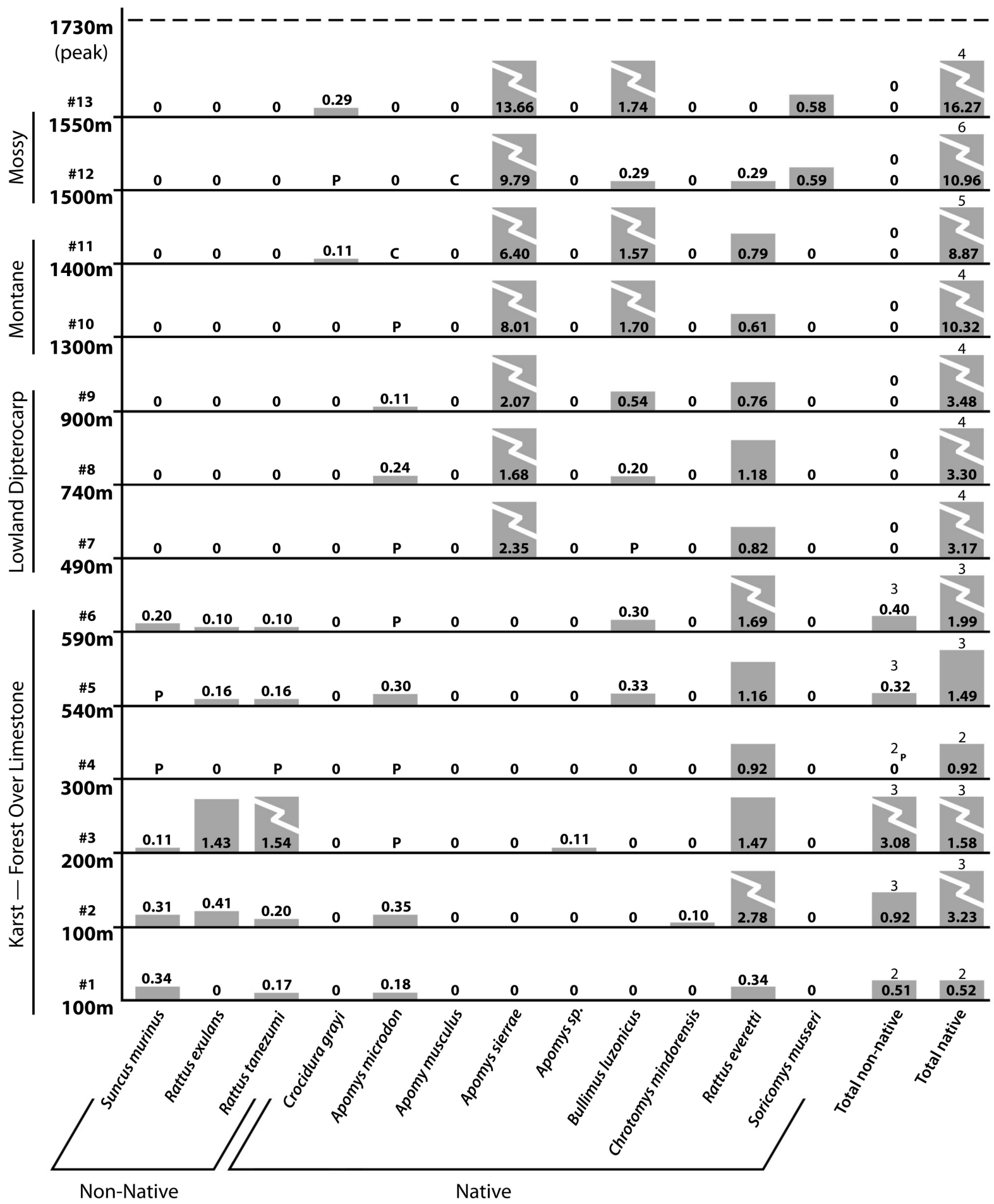

Figure 5. Unweighted relative abundance (per 100 trap-nights) of non-native and native small mammals in the vicinity of Callao Caves and adjacent portions of Mt. Cetaceo (see Methods). Values greater than 1.50 are not shown to scale. Data from Localities 1 through 9 taken from Tables 1 and 4; data from Localities 10-13 taken from Table 1 in Duya et al. (2011). P= presence inferred from captures at elevations above and below the given locality. $\mathrm{C}=$ captured by hand. In the last two right columns for each locality, the upper number is the number of species at that locality trapped, inferred, or captured by hand, and the lower number is the total relative abundance for all member species per 100 trap-nights (see Methods). 
2013b). Additionally, the presence of an unidentified species of mouse in karst (Apomys sp.) points to the need for further study of karstic habitats: perhaps this species is widespread in other karstic areas in the vicinity of the Cagayan River valley, and perhaps endemic species are also present. Further field research in this little-studied habitat is clearly needed.

Paleofauna of Callao Cave. As noted above, two species of small mammals have been reported as fossils from Callao Cave, dated ca. 65,000 BP: Apomys microdon and Batomys sp. (Heaney et al., 2011). We captured A. microdon immediately adjacent to the cave at Localities 1 and 2, as well as at higher elevations (Fig. 5), which indicates its ability to persist not only over much of the Late Pleistocene but also through recent decades of habitat degradation. In contrast, we found no evidence of the persistence of Batomys sp. anywhere along our extensive transect on Mt. Cetaceo in the Sierra Madre, which included habitat like montane and mossy forest where $B$. grant $i$ is moderately common in the Central Cordillera (Heaney et al., 2016a). Although we do not regard our survey as providing conclusive evidence of the absence of Batomys sp. today, it does imply that this species may represent an instance of extinction. If so, this would represent the first or second documented extinction of a native small mammal on Luzon, with the other being the enigmatic Crunomys fallax, which has not been recorded since a single specimen (the holotype), was obtained in 1894 (Thomas, 1898; Heaney et al., 2016a). Further study of fossil small mammals from Callao and adjacent caves (Ochoa, Mijares, and Heaney, unpubl. data) may provide insights into persistence, and possible extinction, of small mammal species in this little-studied region of Luzon.

\section{Acknowledgements}

We take great pleasure in dedicating this paper to Dr. Angel C. Alcala, the "father of modern Philippine biodiversity science," in honor of his many great contributions to our knowledge of Philippine terrestrial and marine biodiversity, to training multiple generations of Philippine biologists, and to his enhancement of Filipino-American research and educational collaboration, and in gratitude for his steadfast encouragement of our studies of the Philippine biota.

We are thankful for the encouragement and support of Regional Executive Director B. Tumaliuan of the Department of Environment and Natural Resources (DENR) - Region II and his staff, Community Environment and Natural Resources Officer M.B. Anzia of Tuguegarao, and Protected Area Superintendent T. Mangantulao and the Protected Area Management Board of the Peñablanca Protected Landscape and Seascape. We thank the Cagayan provincial staff of Callao
Cave for allowing us use of the facilities of the park, and the residents of Agugadan and Naguilatan for their hospitality and assistance as guides, porters, and cooks. We gratefully acknowledge the continuous support and encouragement of the Biodiversity Management Bureau - DENR staff, including Dir. T. M. Lim, J. de Leon, and A. Tagtag. Our fieldwork would not have been successful without the expert assistance of $\mathrm{J}$. Sarmiento, R. Buenviaje and R. Plutado. The figures were ably prepared by A. Niedzielski and L. Nassef; we thank A. Goldman and A. Niedzielski for their assistance with preparing specimens for study, and W. Stanley and J. Phelps for technical support. We gratefully acknowledge financial support for this project provided by the Brown Fund for Mammal Research of the Field Museum and by the Negaunee Foundation.

\section{Literature Cited}

Alviola, P.A., M.R.M. Duya, M.V. Duya, L.R. Heaney and E.A. Rickart, 2011. Mammalian diversity patterns on Mount Palali, Caraballo Mountains, Luzon. Fieldiana: Life and Earth Sciences, 2: 61-74.

Balete, D.S., P.A. Alviola, M.R.M. Duya, M.V. Duya, L.R. Heaney and E.A. Rickart, 2011. The mammals of the Mingan Mountains, Luzon: evidence for a new center of mammalian endemism. Fieldiana Life and Earth Sciences, 2: $75-87$.

Balete, D.S., L.R. Heaney, P.A. Alviola and E.A. Rickart, 2013b. Diversity and distribution of small mammals in the Bicol Volcanic Belt of southern Luzon Island, Philippines. National Museum of the Philippines Journal of Natural History, 1: 61-86.

Balete, D.S., L.R. Heaney and E.A. Rickart, 2013a. The mammals of Mt. Irid, Southern Sierra Madre, Luzon Island. National Museum of the Philippines Journal of Natural History, 1: 15-29.

Balete, D.S., L.R. Heaney, M.J. Veluz and E.A. Rickart, 2009. Diversity patterns of small mammals in the Zambales Mts., Luzon, Philippines. Mammalian Biology, 74: 456-466.

Balete, D.S., E.A. Rickart, L.R. Heaney, P.A. Alviola, M.R.M. Duya, M.V. Duya, T. Sosa and S.A. Jansa, 2012. Archboldomys (Muridae: Murinae) reconsidered: A new genus and three new species of shrew mouse from Luzon Island, Philippines. American Museum Novitates, 3754: 160 .

Bureau of Mines and Geo-sciences, Ministry of Natural Resources, 1982. Geology and Mineral Resources of the Philippines. Vol. 1, Geology. 406 pp.

Detroit, F., A.S. Mijares, J. Corny, G. Daver, C. Zanolli, E. Dizon, E. Robles, R. Grun and P.J. Piper, 2019. A new 
species of Homo from the Late Pleistocene of the Philippines. Nature, 568: 181-186.

Duya, M.R.M., M.V. Duya, P.A. Alviola, D.S. Balete and L.R. Heaney, 2007. Report on a survey of the mammals of the Sierra Madre Range, Luzon Island, Philippines. Banwa, 4:41-68.

Duya, M.R.M., M.V. Duya, P.A. Alviola, D.S. Balete and L.R. Heaney, 2011. Diversity of small mammals in montane and mossy forests on Mount Cetaceo, Cagayan Province, Luzon. Fieldiana Life and Earth Sciences, 2: 88-95.

Fernando, E.S., M.H. Suh, J. Lee, and D.K. Lee, 2008. Forest Formations of the Philippines. ASEAN-Korea Environmental Cooperation Unit, Seoul. 232 pp.

Heaney, L.R., D.S. Balete, P.A. Alviola, M.R.M. Duya and E.A. Rickart, 2013. The mammals of Mt. Anacuao, NE Luzon Island, Philippines: A test of predictions of Luzon small mammal diversity patterns. National Museum of the Philippines Journal of Natural History, 1: 1-13.

Heaney, L.R., D.S. Balete, M.L. Dolar, A.C. Alcala, A.T.L. Dans, P.C. Gonzales, N.R. Ingle, M.V. Lepiten, W.L.R. Oliver, P.S. Ong, E.A. Rickart, B.R. Tabaranza, Jr. and R.C.B. Utzurrum, 1998. A synopsis of the mammalian fauna of the Philippine Islands. Fieldiana Zoology new series, 88: 1-61.

Heaney, L.R., D.S. Balete, M.R.M. Duya, M.V. Duya, S.A. Jansa, S.J. Steppan and E.A. Rickart, 2016b. Doubling diversity: a cautionary tale of previously unsuspected mammalian diversity on a tropical oceanic island. Frontiers of Biogeography, 8.2, e29667, pp. 1-19.

Heaney, L.R., D.S. Balete and E.A. Rickart, 2016a. The Mammals of Luzon Island: Biogeography and Natural History of a Philippine Fauna. Johns Hopkins University Press, Baltimore. $x i+287$ pp.

Heaney, L.R., D.S. Balete, E.A. Rickart, R.C.B. Utzurrum and P.C. Gonzales, 1999. Mammalian diversity on Mt. Isarog, a threatened center of endemism on southern Luzon Island, Philippines. Fieldiana Zoology new series, 95: 1-62.

Heaney, L.R., M.L. Dolar, D.S. Balete, J.A. Esselstyn, E.A. Rickart and J.L. Sedlock, 2010. Synopsis of Philippine Mammals, philippine mammals/

http://www.fieldmuseum.org/

Heaney, L.R., P.D. Heideman, E.A. Rickart, R.B. Utzurrum and J.S.H. Klompen, 1989. Elevational zonation of mammals in the central Philippines. Journal of Tropical Ecology, 5: 259 -280 .

Heaney, L.R., P.J. Piper and A.S.B. Mijares, 2011. The first fossil of endemic murid rodents from the Philippines: a late Pleistocene cave fauna from northern Luzon. Proceedings of the Biological Society of Washington, 124: 234-247.
Jansa, S., K. Barker and L.R. Heaney, 2006. The pattern and timing of diversification of Philippine endemic rodents: Evidence from mitochondrial and nuclear gene sequences. Systematic Biology, 55: 73-88.

Justiniano, R., J.J. Schenk, D.S. Balete, E.A. Rickart, J.A. Esselstyn, L.R. Heaney and S.J. Steppan, 2015. Testing diversification models of endemic Philippine forest mice (Apomys) with nuclear phylogenies across elevational gradients reveal repeated colonization of isolated mountain ranges. Journal of Biogeography, 42: 51-64.

Mallari, N.A.D., B.R. Tabaranza Jr. and M.J. Crosby, 2001. Key Conservation Sites in the Philippines. Bookmark Inc., Makati City. 485 pp.

Mitchell, A.H.G., F. Hernandez and A.P. dela Cruz, 1986. Cenozoic evolution of the Philippine Archipelago. Journal of Southeast Asian Earth Sciences, 1: 3-22.

Ong, P., L.E. Afuang and R.G. Rosell-Ambal (eds.), 2002. Philippine Biodiversity Conservation Priorities: A Second Iteration of the National Biodiversity Strategy and Action Plan. Philippine Department of the Environment and Natural Resources, Quezon City. xviii + 113 pp.

Ong, P. and E.A. Rickart, 2008. Ecology of native and pest rodents in the Philippines. In Singleton, G.R., R.C. Joshi and L.S. Sebastian, eds. Philippine Rats: Ecology and Management. Science City of Muñoz: Philippine Rice Research Institute, pp. 101-115.

Reginaldo, A.A. and A.P.O. de Guia, 2014. Species richness and patterns of occurrence of small non-flying mammals on Mt. Sto. Tomas, Luzon Island, Philippines. Philippine Science Letters, 7: 34-44.

Rickart, E.A., 1993. Diversity patterns of mammals along elevational and disturbance gradients in the Philippines: implications for conservation. Asia Life Sciences, 2: 251260.

Rickart, E.A., D.S. Balete and L.R. Heaney, 2007. Habitat disturbance and the ecology of small mammals in the Philippines. Journal of Environmental Science and Management, 10: 34-41.

Rickart, E.A., D.S. Balete, R.J. Rowe and L.R. Heaney, 2011 b. Mammals of the northern Philippines: tolerance for habitat disturbance and resistance to invasive species in an endemic fauna. Diversity and Distributions, 17: 530-541.

Rickart, E.A., D.S. Balete, R.M. Timm, P.A. Alviola, J.A. Esselstyn and L.R. Heaney, 2019. Two new species of shrew-rats (Rhynchomys: Muridae: Rodentia) from Luzon Island, Philippines. Journal of Mammalogy, 100: 11121129.

Rickart, E.A., L.R. Heaney, D.S. Balete, P.A. Alviola, M.R.M. Duya, M.V. Duya, G. Rosell-Ambal and J.L. Sedlock, 
2013. The mammals of Mt. Natib, Bataan Province, Luzon, Philippines. National Museum of the Philippines Journal of Natural History 1: 31-44.

Rickart, E.A., L.R. Heaney, D.S. Balete and B.R. Tabaranza, Jr., 2011a. Small mammal diversity along an elevational gradient in northern Luzon, Philippines. Mammalian Biology, 76: 12-21.

Rickart, E.A., L.R. Heaney and R.B. Utzurrum, 1991. Distribution and ecology of small mammals along an elevational transect in southeastern Luzon, Philippines. Journal of Mammalogy, 72: 458-469.

Rowsey, D.M., L.R. Heaney and S.A. Jansa, 2018. Diversification rates of the "Old Endemic" murine rodents of Luzon Island, Philippines are inconsistent with incumbency and ecological opportunity. Evolution, 72: $1420-1435$.

Stuart, A.M., C.V. Prescott and G.R. Singleton, 2008. Biology and management of rodent communities in complex agroecosystems -- lowland Philippines. In G.R. Singleton, R.C. Joshi (eds.), Philippine Rats: Ecology and Management. Science City of Muñoz: Philippine Rice Research Institute, pp. 37-55.

Thomas, O. 1898. On the mammals collected by Mr. John Whitehead during his recent expedition to the Philippines, with field notes by the collector. Transactions of the Zoological Society of London, 14: 377-412.

Wolfe, J.A., 1988. Arc magmatism and mineralization in North Luzon and its relationship to subduction at the East Luzon and North Manila Trenches. Journal of Southeast Asian Earth Sciences, 2: 79-93.

Yumul, G., Jr., C. Dimalanta, K. Queano and E. Marquez, 2009. Philippines, Geology. In R.G. Gillespie and D.A. Clague (eds.), Encyclopedia of Islands. University of California Press, Berkeley, pp. 732-738. 